\title{
Mitochondrial DNA copy number and biogenesis in different tissues of early- and late-lactating dairy cows
}

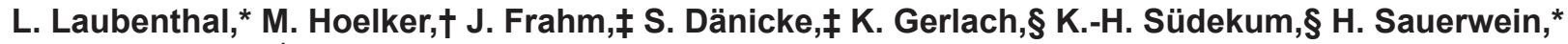 \\ and S. Häussler*1 \\ *Institute of Animal Science, Physiology and Hygiene Unit, and \\ †Institute of Animal Science, Animal Breeding and Husbandry Unit, University of Bonn, 53115 Bonn, Germany \\ łInstitute of Animal Nutrition, Friedrich-Loeffler-Institute (FLI), Federal Research Institute for Animal Health, 38116 Braunschweig, Germany \\ §Institute of Animal Science, Animal Nutrition Group, University of Bonn, 53115 Bonn, Germany
}

\begin{abstract}
Energy balance in dairy cows changes during the course of lactation due to alterations in voluntary feed intake and energy required for milk synthesis. To adapt to the demands of lactation, energy metabolism needs to be regulated and coordinated in key organs such as adipose tissue (AT), liver, and mammary gland. Mitochondria are the main sites of energy production in mammalian cells and their number varies depending on age, organ, and physiological condition. The copy number of the mitochondrial genome, the mitochondrial DNA (mtDNA), reflects the abundance of mitochondria within a cell and is regulated by transcriptional and translational factors. Environmental, physiological, and energetic conditions change during lactation and we thus hypothesized that these changes may influence the mtDNA copy number and the abundance of genes regulating mitochondrial biogenesis. Therefore, we aimed to provide an overview of mitochondrial biogenesis in liver, subcutaneous (sc)AT, mammary gland, and peripheral blood cells during early and late lactation in dairy cows. German Holstein cows $(\mathrm{n}=21)$ were fed according to their requirements, and biopsies from scAT, liver, mammary gland, and blood were collected in early and late lactation and assayed for relative mtDNA copy numbers and the mRNA abundance of genes regulating mitochondrial biogenesis, such as nuclearrespiratory factor 1 and 2 ( $N R F-1, N R F-2)$, mitochondrial transcription factor A $(T F A M)$, and peroxisome proliferator-activated receptor-gamma coactivator $1-\alpha$ $(P G C-1 \alpha)$. The number of mtDNA copies increased from early to late lactation in all tissues, whereas that in peripheral blood cells was greater in early compared with late lactation. Moreover, mitochondrial activity enzymes (i.e., citrate synthase and cytochrome $c$
\end{abstract}

Received May 21, 2015.

Accepted October 8, 2015.

${ }^{1}$ Corresponding author: susanne.haeussler@uni-bonn.de oxidase) increased from early to late lactation in scAT. Comparing the number of mtDNA copies between tissues and blood in dairy cows, the highest mtDNA content was observed in liver. The mRNA abundance of genes related to mitochondrial biogenesis changed in a tissue-specific manner when comparing early versus late lactation. The mtDNA copy number was associated with transcriptional factors only in AT, suggesting nontranscriptional regulation of mtDNA in the other tissues. We detected strong correlations between peripheral blood mtDNA and tissue mtDNA content in early lactation. Peripheral blood forms an appropriate medium to display the cellular content of mtDNA copy numbers and consequently the cellular energy status of tissues during early lactation.

Key words: dairy cow, mitochondrial biogenesis, mitochondrial DNA copy number

\section{INTRODUCTION}

The rapidly increasing milk synthesis after calving can dramatically change the energy metabolism of key organs, such as the mammary gland, liver, and adipose tissue (AT), of high-yielding dairy cows (Barber et al., 1997; Block et al., 2001). In many cases, an approximately 4-fold increase in energy demands in early-lactating cows compared with pregnant and nonlactating animals (Block et al., 2001), accompanied by a decrease in voluntary feed intake, results in a period of negative energy balance (EB). This energy deficit is primarily compensated for by the mobilization of body reserves. Fatty acids (FA) are released from AT into the circulation (Castañeda-Gutiérrez et al., 2009). In the mammary gland, FA are re-esterified into triacylglycerols (TAG) and secreted into the milk, whereas in the liver, they are oxidized to $\mathrm{CO}_{2}$, converted to ketone bodies, or re-esterified into TAG and secreted in very low density lipoproteins. Excessive accumulation of liver TAG has been associated with diverse economically important diseases, including hepatic lipidosis and 
ketosis (Drackley, 1999). With advancing lactation, the AT depots are refilled by lipogenic processes in times of a positive $\mathrm{EB}$ in late lactation and the beginning of the dry period.

At the cellular level, alterations of nutrient and energy requirements coincide with changes in the mitochondria, the main sites of high-yielding ATP-generating reactions in mammalian cells. Their number varies depending on age, sex, organ, and physiological or pathological conditions (Fawcett, 1981). The mitochondrial DNA (mtDNA); that is, the mitochondrial genome, reflects the abundance of mitochondria within a cell and can vary according to the energy demands of the cell (Al-Kafaji and Golbahar, 2013). Proliferation and differentiation of mitochondria and mtDNA are regulated and maintained by genes involved in the mitochondrial biogenesis, such as nuclear-respiratory factor 1 and 2 (NRF-1, NRF-2), mitochondrial transcription factor A $(\boldsymbol{T F A} \boldsymbol{M})$, and the peroxisome proliferator-activated receptor-gamma coactivator $1-\alpha(P G C-1 \alpha$; Izquierdo et al., 1995). These transcription factors can control the amount and function of mtDNA in various tissues; for example, human AT (Villarroya et al., 2009), as well as liver and muscle tissue (Pejznochova et al., 2010). The mtDNA decreases with age, as shown in mice and humans, whereby mtDNA varies between different tissues (Barazzoni et al., 2000).

However, little is known about mitochondria and the effect of mitochondrial biogenesis in the mammary gland, liver, and AT, as well as in peripheral blood cells of lactating dairy cows. Thus, we aimed to analyze mtDNA copy numbers and genes regulating mitochondrial biogenesis in the aforementioned physiologically relevant key organs during early and late lactation. In addition, mitochondrial activity enzymes (i.e., citrate synthase and cytochrome $c$ oxidase) were measured in AT. Furthermore, we aimed to determine whether the mtDNA copy number in circulating blood cells may serve as an appropriate marker for tissue mtDNA content.

\section{MATERIALS AND METHODS}

\section{Animals, Experimental Design, and Sample Collection}

The animal trial was approved by the State Agency for Nature, Environment and Consumer Protection of North Rhine-Westphalia (Recklinghausen, Germany; File Number 84-02.05.20.12.160) and was conducted at the research station Frankenforst of the Faculty of Agriculture, University of Bonn (Königswinter, Germany). In total, 21 German Holstein cows (lactation number:
1 to 5) were fed according to the recommendations of the Society of Nutrition Physiology in Germany (GfE, 2001) with a partial mixed ration (6.3-6.8 $\mathrm{MJ}$ of $\mathrm{NE}_{\mathrm{L}} /$ $\mathrm{kg}$ of DM) offered for ad libitum intake and concentrate feed (7.7 MJ of $\mathrm{NE}_{\mathrm{L}} / \mathrm{kg}$ of $\mathrm{DM}$ ) depending on the individual's milk yield. Animals were housed in a freestall barn with an adjacent milking parlor and were milked twice per day. Based on the equations published by the GfE (2001), the $\mathrm{NE}_{\mathrm{M}}, \mathrm{NE}_{\mathrm{L}}$, and milk energy concentration were calculated as follows:

$$
\begin{gathered}
\mathrm{NE}_{\mathrm{M}}\left(\mathrm{MJ} \text { of } \mathrm{NE}_{\mathrm{L}} / \mathrm{d}\right)=0.293 \times \mathrm{kg} \text { of } \mathrm{BW}^{0.75}, \\
\text { Milk energy concentration }\left(\mathrm{MJ} \text { of } \mathrm{NE}_{\mathrm{L}} / \mathrm{kg}\right)= \\
0.38 \times \text { fat }(\%)+0.21 \times \text { protein }(\%)+0.95, \text { and } \\
\mathrm{NE}_{\mathrm{L}}=\text { milk energy concentration }\left(\mathrm{MJ} \text { of } \mathrm{NE}_{\mathrm{L}} / \mathrm{kg}\right) \\
\times \text { milk yield }(\mathrm{kg} / \mathrm{d}) .
\end{gathered}
$$

Fat and protein content of the milk were given by fixed values of $4 \%$ fat and $3.4 \%$ protein (GfE, 1991).

The net energy balance was calculated with the following equation:

$$
\begin{aligned}
& \text { Net energy balance }\left(\mathrm{MJ} \text { of } \mathrm{NE}_{\mathrm{L}} / \mathrm{d}\right)=\text { energy intake } \\
& \qquad \begin{array}{c}
\left(\mathrm{MJ} \text { of } \mathrm{NE}_{\mathrm{L}} / \mathrm{d}\right)-\left[\mathrm{NE}_{\mathrm{M}}\left(\mathrm{MJ} \text { of } \mathrm{NE}_{\mathrm{L}} / \mathrm{d}\right)\right. \\
\left.+\mathrm{NE}_{\mathrm{L}}\left(\mathrm{MJ} \text { of } \mathrm{NE}_{\mathrm{L}} / \mathrm{d}\right)\right] .
\end{array}
\end{aligned}
$$

Body weight $(\mathrm{kg})$, milk yield $(\mathrm{kg})$, and feed intake $(\mathrm{kg})$ were recorded daily. For EB and milk yield, weekly means were used. Body condition was scored on the day of the biopsies (BCS, according to the 5-scale system; Edmonson et al., 1989).

On the day of the biopsy, blood samples were collected from the jugular vein immediately before sedation of the cows and were kept on ice thereafter. To obtain serum and heparinized plasma, respectively, samples were centrifuged $\left(15 \mathrm{~min}, 3,000 \times g, 4^{\circ} \mathrm{C}\right)$ and stored at $-80^{\circ} \mathrm{C}$ until analyzes. Blood DNA was isolated from whole heparinized blood.

Biopsies from subcutaneous (sc) AT of the tailhead region, liver, and mammary gland were taken in early (between 21 and 28 DIM) and late lactation (between 245 and 252 DIM). Before the biopsies, the animals were sedated by intravenous injection of $1 \mathrm{~mL}$ of Xylazine ( $2 \%$, Serumwerk Bernburg AG, Germany).

The biopsy sites were washed, shaved, and sterilized with $70 \%$ ethanol. The biopsy area was locally anaesthetized by sc injection of lidocaine (liver: $10 \mathrm{~mL}$; mammary gland: $1 \mathrm{~mL}$; scAT: $20 \mathrm{~mL} ; 2 \%$; Bela-Pharm GmbH \& Co. KG, Vechta, Germany). 
Liver biopsies were obtained by liver puncture in the 10th intercostal space, and 60 to $80 \mathrm{mg}$ of tissue was taken using a 12-gauge $\times 20$-cm Core Tissue Biopsy Needle with a Bard Magnum Biopsy instrument (Bard Magnum, Covington, GA). For mammary gland biopsies, a 0.2 - to $0.3-\mathrm{cm}$ skin incision was made and 2 mammary tissue cores (30 to $60 \mathrm{mg}$ each) were taken using a Core Tissue Biopsy Needle (12-gauge $\times 10$ $\mathrm{cm}$; Bard Magnum). The second biopsy was made on the contralateral side of the first biopsy. For the scAT biopsies, a 5.0-cm skin incision was made in the region of the tailhead, and scAT from the underlying fat layer was collected. The second biopsy was made on the contralateral side of the first biopsy.

All biopsy samples were rinsed in sterile saline, snap frozen in liquid nitrogen, and stored at $-80^{\circ} \mathrm{C}$ until further analyses. The areas of the incisions were treated with an oxytetracycline-hydrochloride spray (Intervet Deutschland GmbH, Unterschleißheim, Germany).

\section{Gene Expression Assays}

Extraction of total RNA and synthesis of cDNA was done as described by Saremi et al. (2012). Quantitative PCR (qPCR) analysis was carried out using a Mx3000P cycler (Stratagene, Agilent Technologies, Santa Clara, CA). Each run included an inter-run calibrator, a negative template control for $\mathrm{qPCR}$, and a negative template control as well as a no-reverse-transcriptase control for cDNA. The quantification of samples was performed against a cDNA standard curve with serial dilutions. The results of the genes of interest $(N R F-1$, NRF-2, TFAM, PGC-1 $\alpha$ ) were normalized based on the geometric mean of the amplified reference genes. The most stable reference genes for the different tissues were selected as described by Hosseini et al. (2010) using qBASE ${ }^{\text {plus }} 2.0$ (Biogazelle, Ghent, Belgium): EIF3K (eukaryotic translation initiation factor 3) and $E M D$ (emerin) were used for liver samples; POLR2A (RNA polymerase II) and $E M D$ were selected for AT samples; and LRP10 (lipoprotein receptor-related protein 10) and $H P C A L$ (hippocalcin-like 1) were used for mammary gland samples.

\section{DNA Isolation and Multiplex qPCR}

The number of mtDNA copies per cell was assessed by multiplex qPCR (Cawthon, 2009). Total genomic DNA from scAT biopsies was extracted by a commercially available DNA isolation kit (PowerPlant Pro DNA Isolation Kit; MoBio, Carlsbad, CA) according to the manufacturer's protocol. Total DNA from whole blood, liver, and mammary gland was isolated using the Wizard Genomic DNA Purification Kit (Promega, Mannheim, Germany) according to the manufacturer's protocol. The concentration and purity of total DNA were controlled by absorbance readings at $260 \mathrm{~nm}$ and $280 \mathrm{~nm}$ using the Nanodrop 1000 spectrophotometer (peQLab Biotechnology, Erlangen, Germany); the integrity of the DNA obtained was assessed by gel electrophoresis. Ten nanograms per microliter of total DNA was mixed with 2 pairs of primers. To determine the relative quantity of mtDNA products, $12 \mathrm{~S}$ rRNA, a gene specific in the mitochondrial genome, and bovine $\beta$-globin, a housekeeping gene acting as a nuclear control gene with a known copy number of 2 per each cell, were used (Brown et al., 2012). The specificity of both primers was controlled by gel electrophoresis. A multiplex qPCR was set up by adding $10 \mu \mathrm{L}$ of Dynamo SYBR Green (Thermo Scientific, Rockford, IL) and $0.12 \mu \mathrm{L}$ of ROX as passive reference dye (Thermo Scientific), both (12S rRNA and $\beta$-globin) forward and reverse primers (1 $\mu \mathrm{L}$ each; Table 1), and nuclease-free water to the DNA samples for a final volume of $20 \mu \mathrm{L}$. The PCR conditions were modified to the protocol reported by Brown et al. (2012). A DNA standard curve was used to estimate PCR efficiency for each qPCR run and a pooled DNA sample served as inter-run calibrator. The relative mtDNA copy numbers versus total DNA were calculated according to Nicklas et al. (2004):

$$
\begin{aligned}
& \text { Relative mtDNA copy number per cell }= \\
& \beta \text {-globin copy number }(2 \text { copies per cell }) \\
& \times \text { PCR efficiency }{ }^{-(\mathrm{Ct} 12 \mathrm{~S} \text { rRNA }-\mathrm{Ct} \beta \text {-globin })}
\end{aligned}
$$

where $\mathrm{Ct}=$ cycle threshold.

\section{Citrate Synthase and Cytochrome c Oxidase Activity}

For the preparation of AT extracts, scAT samples were homogenized in 2 volumes of cell lysis buffer [10 $\mathrm{m} M$ Tris- $\mathrm{HCl}(\mathrm{pH}$ 7.4), $100 \mathrm{~m} M \mathrm{NaCl}, 1 \mathrm{~m} M$ EGTA, 1 $\mathrm{m} M$ EDTA, $1 \%$ Triton, $0.5 \%$ Na-deoxycholate, $1 \mathrm{mM}$ $\mathrm{NaF}, 20 \mathrm{~m} M$ Na-pyrophosphate, $2 \mathrm{~m} M$ Na-orthovanadate, $0.1 \%$ SDS, $10 \%$ glycerol], including 1 tablet $/ 10$ $\mathrm{mL}$ buffer complete protease inhibitor cocktail (Roche, Mannheim Germany)] and PhosStop (Sigma-Aldrich, St-Louis, MO) as well as $2.3 \mathrm{mg} / 10 \mathrm{~mL}$ lysis buffer Pefabloc (Sigma-Aldrich) using a homogenizer (Precellys 24, Peqlab, Erlangen, Germany). Homogenates were centrifuged (twice at $14,000 \times g, 10 \mathrm{~min}, 4^{\circ} \mathrm{C}$ ) and the fat layer was removed.

The activities of citrate synthase (CS; Kit CS0720; Sigma-Aldrich) and cytochrome $c$ oxidase (Cox; Kit CYTOCOX1; Sigma-Aldrich) were determined in the 
scAT extracts. Total protein in AT extracts was quantified by the Bradford assay (Roti-Nanoquant K880, Roth, Karlsruhe, Germany). For each sample, $1.37 \mu \mathrm{g}$ of protein was used for both measurements. The activities of CS and Cox were determined in triplicate. The reaction of CS was based on the formation of 2-nitro5 -thiobenzoic acid, and absorbance was measured every $15 \mathrm{~s}$ for $3 \mathrm{~min}$ spectrophotometrically at $412 \mathrm{~nm}$ $\left(28^{\circ} \mathrm{C}\right.$ ) using a microplate reader (Synergy H1, BioTek, Winooski, VT) as described in the manufacturer's instructions. The oxidation of ferrocytochrome $c$ by Cox was measured at $550 \mathrm{~nm}$ every $15 \mathrm{~s}$ for 3 min using a microplate reader (Synergy H1) following the manual.

For positive controls, AT extracts were replaced either by CS or Cox control enzyme, whereas for negative control, the sample was replaced with water. Data are presented as nanomoles per minute per milligram of protein.

\section{Analysis of Blood Variables}

The concentrations of BHB, FA, albumin, total protein, glucose, cholesterol, and triglycerides as well as the activities of aspartate aminotransferase (AST), $\gamma$-glutamyltransferase (GGT), and glutamate dehydrogenase (GLDH) were determined in serum samples by using an automatic clinical chemistry analyzer (Eurolyser CCA180, Eurolab, Hallein, Austria).

\section{Variables Indicative of Oxidative Stress}

Oxidative stress was characterized in serum by assessing the derivatives of reactive oxygen metabolites (dROM) by a spectrophotometric test using $N, N$-diethyl-para-phenylendiamine as chromogenic substrate (Alberti et al., 2000) according to the modified protocol of Regenhard et al. (2014). The resulting values were calculated from the standard curves by linear regression and are expressed as $\mathrm{H}_{2} \mathrm{O}_{2}$ equivalents.

The formation of lipid peroxides was measured in serum using a biochemical assay kit for thiobarbituric acid reactive substances (TBARS; BioAssay Systems, Hayward, CA) according to the manufacturer's protocol. In brief, $100 \mu \mathrm{L}$ of serum was mixed with $200 \mu \mathrm{L}$ of $10 \%$ trichloroacetic acid, incubated for $5 \mathrm{~min}$ on ice, and centrifuged at $18,000 \times g$ for 6 min at $4^{\circ} \mathrm{C}$. For the standard curve, different dilutions (2 to $0.125 \mu M$ ) of malondialdehyde in $\mathrm{H}_{2} \mathrm{O}$ were used. For the color reaction, $200 \mu \mathrm{L}$ of thiobarbituric acid was added to the samples and standards, followed by incubation at $100^{\circ} \mathrm{C}$ for $60 \mathrm{~min}$. Optical densities were measured at 515 and $535 \mathrm{~nm}$ by a microplate reader (Synergy H1). The TBARS concentrations $(\mu \mathrm{mol} / \mathrm{L})$ were calculated according the manufacturer's protocol.

\section{Measurement of the Hepatocyte Areas}

Liver biopsies were snap frozen in tissue freezing medium (Leica, Wetzlar, Germany) and stored at $-80^{\circ} \mathrm{C}$ until cutting. Liver $(6 \mu \mathrm{m})$ sections were cut using a cryostat (Leica) and mounted on SuperFrost Plus slides (Menzel, Braunschweig, Germany). Frozen tissue sections were fixed in acetone, stained with hematoxylin (Merck, Darmstadt, Germany) after drying, and mounted with Kaiser's glycerol gelatin (Merck). From each stained section, 5 images were randomly taken at $100 \times$ magnification on a light microscope (Leica DMR, Leica Microsystems, Wetzlar, Germany) with a JVC digital color camera KY-F75U (Hachioji Plant of Victor Company, Tokyo, Japan) The hepatocyte area $\left(\mu \mathrm{m}^{2}\right)$ of each 50 hepatocytes per section was assessed using the Diskus software (version 4; Hilgers, Königswinter, Germany) and averaged afterward.

\section{Statistical Analyses}

Statistical analyses were performed using SPSS version 22.0 (SPSS Inc., Chicago, IL). Data for all variables were tested for normal distribution using the Kolmogorov-Smirnov test and for homogeneity of variances by the Levene test. Not normally distributed variables as well as mRNA values were log-transformed and back transformed to the original scale after calculation. With regard to the homogeneity of variances, differences between early and late lactation were compared by the paired Student's $t$-test $(P \leq 0.05)$ and differences between tissues were analyzed using the nonpaired Student's $t$-test $(P \leq 0.05)$. The mixed model procedure including Bonferroni post hoc tests was used to analyze EB and milk yield. All values are expressed as means \pm SEM. Correlations were assessed by Spearman analysis (Spearman $\rho$ ). Results with a $P$-value $\leq 0.05$ were considered significant, and $0.05<$ $P \leq 0.1$ was set as a trend.

\section{RESULTS}

\section{Body Condition and Blood Variables}

The results from variables describing body condition and from blood variables are shown in Table 2. From early to late lactation, BW and BCS increased 1.1-fold $(P=0.002)$ and 1.3 -fold $(P<0.001)$, respectively. Net EB and milk yield increased during the course of lactation $(P<0.001$, Figure 1$)$, whereas energy requirements decreased by $22 \%$ from early to late lactation $(P=0.004$; Table 2). In addition, FA and BHB concentrations decreased by $51 \%(P<0.001)$ and $38 \%$ $(P=0.002)$, respectively, from early to late lactation. 
Table 1. Sequences of the primers used for quantification of target and reference genes

\begin{tabular}{|c|c|c|c|}
\hline Item $^{1}$ & \multicolumn{2}{|c|}{ Primer sequence $^{2}\left(5^{\prime}\right.$ to $\left.3^{\prime}\right)$} & Accession no. \\
\hline \multicolumn{4}{|l|}{ Gene } \\
\hline TFAM & ATGCTTACAGGGCAGACTGG & AGCTTTACCTGTGATGTGCCA & NM_001034016.2 \\
\hline$N R F-1$ & CCCAAACTGAGCACATGG & GTTAAGTATGTCTGAATCGTC & NM_001098002.2 \\
\hline$N R F-2$ & TTCCAGCATCAGTGCAGTCT & CTGGCCATTGTTTCCTGTTC & NM_001075437.2 \\
\hline$H P C A L$ & CCATCGACTTCAGGGAGTTC & CGTCGAGGTCATACATGCTG & NM001098964 \\
\hline LRP10 & CCAGAGGATGAGGACGATGT & ATAGGGTTGCTGTCCCTGTG & BC149232 \\
\hline POLR2A & GAAGGGGGAGAGACAAACTG & GGGAGGAAGAAGAAAAAGGG & X63564 \\
\hline \multicolumn{4}{|l|}{ MtDNA $^{3}$ copy number } \\
\hline $12 \mathrm{~S}$ rRNA & CGCGGTCATACGATTAACCC & AACCCTATTTGGTATGGTGCTT & NM_U01920.1 \\
\hline$\beta_{- \text {Globin }^{2}}$ & CGGCGGCGGGCGGCGCGGGCTGGG & GCCGGCCCGCCGCGCCCGTCCCGCCG & \\
\hline & CGGGAAGGCCCATGGCAAGAAGG & CTCACTCAGCGCAGCAAAGG & \\
\hline
\end{tabular}

${ }^{1} P G C-1 \alpha=$ peroxisome proliferator-activated receptor gamma coactivator $1-\alpha ; T F A M=$ mitochondrial transcriptional factor $\mathrm{A} ; N R F-1=$ nuclear respiratory factor $1 ; N R F-2=$ nuclear respiratory factor $1 ; E M D=$ emerin; EIF3K= eukaryotic translation initiation factor 3 ; $H P C A L$ $=$ hippocalcin-like $1 ; L R P 10=$ lipoprotein receptor-related protein $10 ; P O L R 2 A=\mathrm{RNA}$ polymerase $\mathrm{II} ; 12 \mathrm{~S} \mathrm{rRNA}=$ mitochondrial encoded $12 \mathrm{~S}$ ribosomal RNA.

${ }^{2}$ Primer sequences adopted from Brown et al. (2012).

${ }^{3} \mathrm{MtDNA}=$ mitochondrial DNA.

The serum concentrations of dROM and TBARS did not differ between early and late lactation. Hepatocyte areas were not affected by stage of lactation. The serum concentrations of cholesterol, triglycerides, and the activity of GGT and GLDH were increased $(P \leq 0.05)$ from early to late lactation, whereas no time effect was observed for albumin, total protein, glucose, or AST.

\section{Tissue-Specific and Lactation-Driven Differences in mtDNA Copy Number}

The number of mtDNA copies per cell was determined in scAT, liver, and mammary gland as well as in peripheral blood in early and late lactation. In late lactation, blood mtDNA copy numbers were almost half

Table 2. Body condition, performance, hepatocyte area, and blood variables of dairy cows $(\mathrm{n}=21)$ during early (21 to $28 \mathrm{DIM})$ and late (245 to 252 DIM) lactation (means \pm SEM)

\begin{tabular}{lcc}
\hline & \multicolumn{2}{c}{ Lactation } \\
\cline { 2 - 3 } Item & Early & Late \\
\hline Energy balance $\left(\mathrm{MJ}\right.$ of $\left.\mathrm{NE}_{\mathrm{L}} / \mathrm{d}\right)$ & $-6.89 \pm 3.83^{\mathrm{a}}$ & $17.4 \pm 4.31^{\mathrm{b}}$ \\
Milk yield $(\mathrm{kg} / \mathrm{d})$ & $33.2 \pm 1.72^{\mathrm{a}}$ & $22.8 \pm 1.33^{\mathrm{b}}$ \\
BW $(\mathrm{kg})$ & $627 \pm 12.8^{\mathrm{a}}$ & $657 \pm 14 .^{\mathrm{b}}$ \\
BCS & $2.4 \pm 0.1^{\mathrm{a}}$ & $3.0 \pm 0.1^{\mathrm{b}}$ \\
Energy requirements $\left(\mathrm{MJ}\right.$ of $\left.\mathrm{NE}_{\mathrm{L}} / \mathrm{d}\right)$ & $132 \pm 8.3^{\mathrm{a}}$ & $103 \pm 5.7^{\mathrm{b}}$ \\
Hepatocyte area $\left(\mu \mathrm{m}^{2}\right)$ & $213 \pm 6.15$ & $224 \pm 5.88$ \\
Blood variables & & \\
Fatty acid $(\mathrm{mmol} / \mathrm{L})$ & $0.49 \pm 0.04^{\mathrm{a}}$ & $0.24 \pm 0.02^{\mathrm{b}}$ \\
BHB $(\mathrm{mmol} / \mathrm{L})$ & $0.92 \pm 0.09^{\mathrm{a}}$ & $0.57 \pm 0.06^{\mathrm{b}}$ \\
dROM $\left(\mu \mathrm{g}\right.$ of $\mathrm{H}_{2} \mathrm{O}_{2}$ equivalents/mL) & $76.9 \pm 7.40$ & $82.0 \pm 8.3$ \\
TBARS $(\mu \mathrm{mol} / \mathrm{L})$ & $0.22 \pm 0.02$ & $0.22 \pm 0.17$ \\
Albumin $(\mathrm{g} / \mathrm{L})$ & $37.0 \pm 0.93$ & $37.7 \pm 0.60$ \\
Total protein $(\mathrm{g} / \mathrm{L})$ & $71.9 \pm 1.26$ & $73.8 \pm 1.16$ \\
Glucose $(\mathrm{mg} / \mathrm{dL})$ & $52.2 \pm 2.98$ & $56.9 \pm 2.75$ \\
Cholesterol $(\mathrm{mg} / \mathrm{dL})$ & $115 \pm 5.42^{\mathrm{a}}$ & $183 \pm 6.95^{\mathrm{b}}$ \\
Triglycerides $(\mathrm{mg} / \mathrm{dL})$ & $8.26 \pm 0.61^{\mathrm{a}}$ & $10.1 \pm 0.68^{\mathrm{b}}$ \\
AST $(\mathrm{U} / \mathrm{L})$ & $81.3 \pm 3.80$ & $90.2 \pm 6.84$ \\
GGT $(\mathrm{U} / \mathrm{L})$ & $20.9 \pm 1.79^{\mathrm{a}}$ & $30.0 \pm 3.92^{\mathrm{b}}$ \\
GLDH $(\mathrm{U} / \mathrm{L})$ & $15.4 \pm 2.32^{\mathrm{a}}$ & $19.3 \pm 1.93^{\mathrm{b}}$ \\
\hline
\end{tabular}

${ }_{\mathrm{a}, \mathrm{b}}$ Means with different letters indicate significant differences between early and late lactation $(P \leq 0.05)$.

${ }^{1} \mathrm{dROM}=$ derivatives of oxygen metabolites; TBARS $=$ thiobarbituric acid reactive substances; AST $=$ aspartate aminotransferase; GGT $=\gamma$-glutamyltransferase; GLDH $=$ glutamate dehydrogenase. 
that present in early lactation $(P=0.008$; Figure $2 \mathrm{~A})$. Within scAT, mtDNA copy number increased 1.7-fold $(P<0.001)$ from early to late lactation (Figure $2 \mathrm{~B})$. Furthermore, mtDNA copies in liver were 1.2-fold $(P<$ 0.001 ; Figure 2C) and in mammary gland 1.3-fold $(P=$ 0.057; Figure 2D) greater in late versus early lactation.

When comparing the number of mtDNA copies between the tissues investigated and blood cells, the greatest mtDNA content was observed in liver, being about 6.5-, 5.2-, and 5.8-fold higher $(P<0.001)$ than in AT, mammary gland, and blood cells, respectively.

\section{CS and Cox Activities in AT}

The activity of CS and Cox in AT are presented in Figure 3. In late lactation, CS activity was about 2.4 -fold greater than in early lactation $(P<0.001)$. Across all data, CS activity was positively related to mtDNA copy numbers in scAT $(\rho=0.689 ; P<0.001)$. When correlating CS activity with mtDNA copy number within sampling time, the positive correlation was limited to late lactation ( $\rho=0.622 ; P=0.003)$.

From early to late lactation, the activity of Cox was increased 1.9-fold $(P=0.002)$. Irrespective of the stage of lactation, Cox activity was positively associated with mtDNA copy numbers in scAT $(\rho=0.491 ; P=0.001)$, whereas no relation was observed when considering early and late lactation separately. The ratio between Cox and CS was similar in early and late lactation.

\section{Tissue-Specific and Lactation-Driven Changes of Genes Related to Mitochondrial Biogenesis}

The mRNA abundances of key transcription factors of mitochondrial biogenesis (NRF-1, NRF-2, TFAM, and $P G C-1 \alpha$ ) during early and late lactation in scAT, liver, and mammary gland are presented in Figure 4. The mRNA abundances of NRF-1,NRF-2, and TFAM in liver remained constant, whereas that of $P G C-1 \alpha$ decreased by $25 \%(P=0.017$; Figure $4 \mathrm{~A})$ from early to late lactation. Within scAT, the mRNA abundances of NRF-2 and TFAM increased 1.2-fold $(P=0.036)$ and 1.4-fold $(P=0.004)$, respectively, whereas $N R F-1$ expression decreased by $11 \%$ from early to late lactation $(P=0.022$; Figure $4 \mathrm{~B})$. The mRNA abundance of $P G C-1 \alpha$ in mammary gland increased 1.3 -fold from early to late lactation $(P=0.006$, Figure $4 \mathrm{C})$.

\section{Correlations Between mRNA Abundance of Mitochondrial Biogenesis Genes and mtDNA Copy Number}

The correlations between mtDNA copy numbers and mRNA abundance of NRF-1, NRF-2, $P G C-1 \alpha$, and TFAM in different tissues are shown in Table 3. The BCS was positively correlated with scAT mtDNA copy number $(\rho=0.322 ; P=0.038)$ and negatively correlated with mtDNA copy number in blood cells $(\rho=$ $-0.420 ; P=0.006)$.

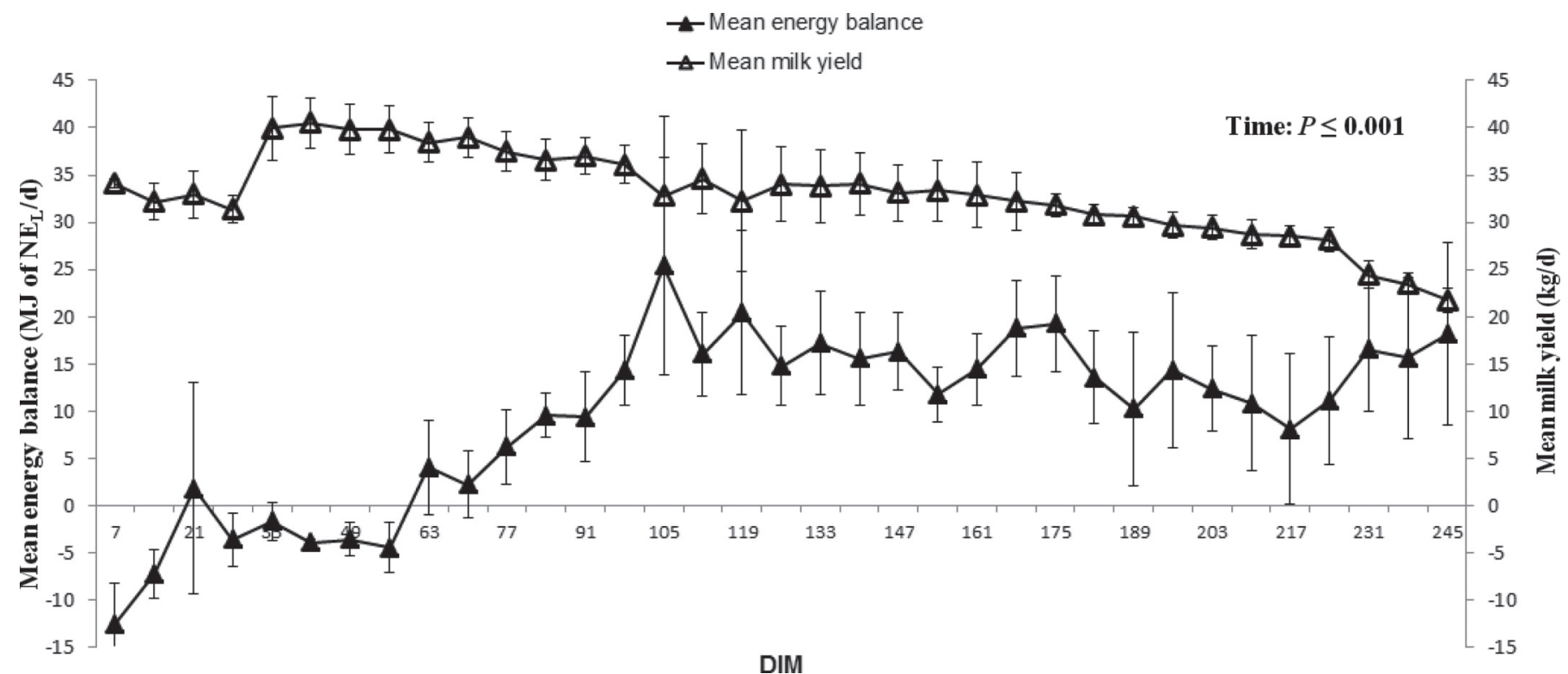

Figure 1. Development of net energy balance (means \pm SEM) and milk yield (means \pm SEM) in high-yielding dairy cows $(\mathrm{n}=21)$ from 7 to 245 DIM. $P \leq 0.05$. 
A

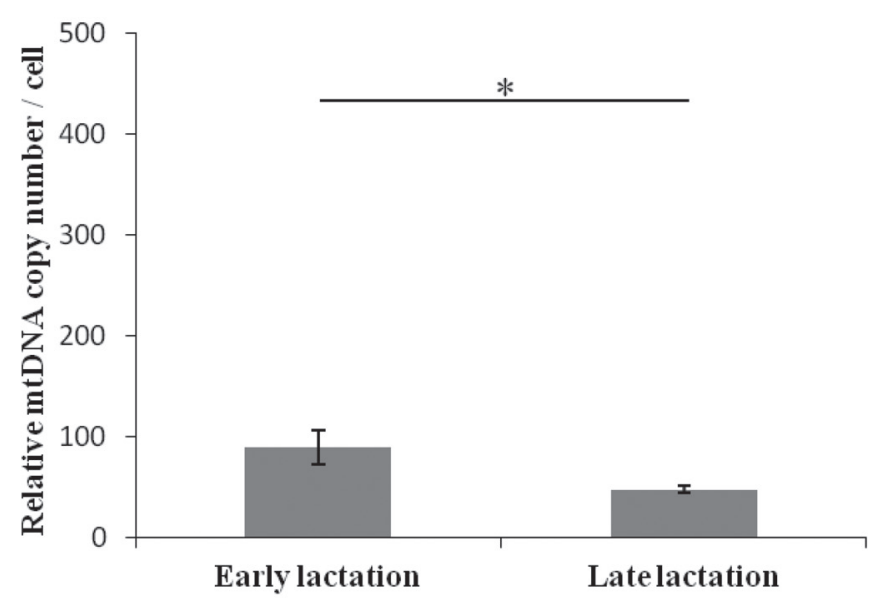

C

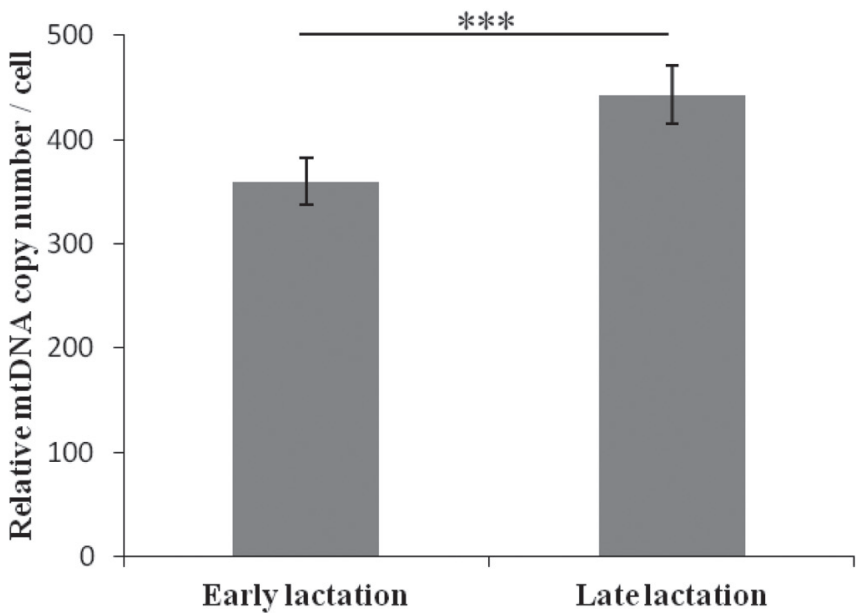

B

Adipose tissue

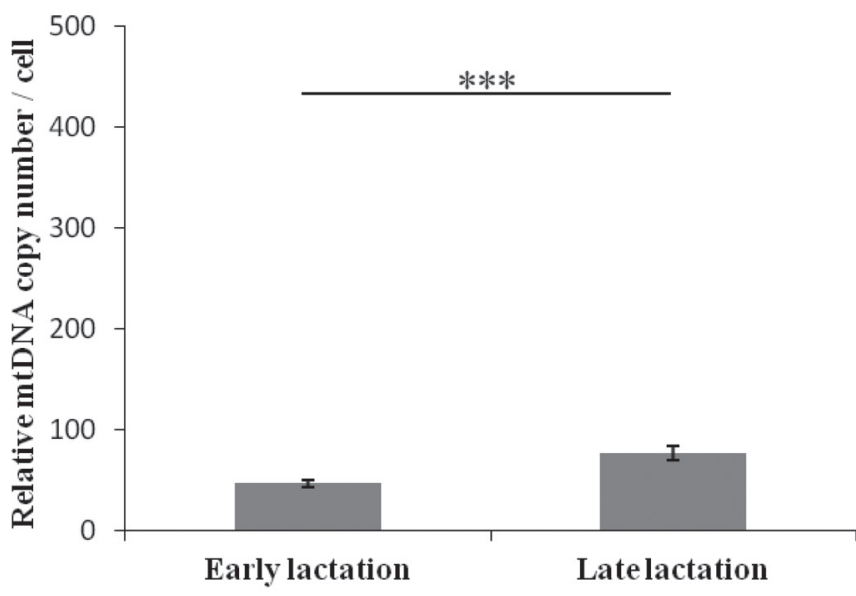

D

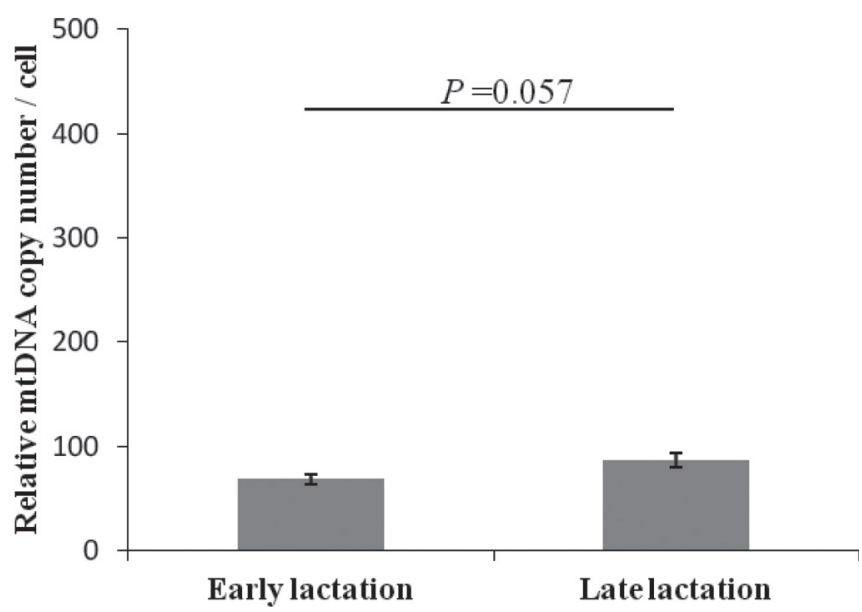

Figure 2. Mitochondrial DNA (mtDNA) copy numbers per cell (means \pm SEM) in different tissues in early and in late lactation. Blood (A; $n$ $=21)$, adipose tissue $(\mathrm{B} ; \mathrm{n}=21)$, liver $(\mathrm{C} ; \mathrm{n}=21)$ and mammary gland $(\mathrm{D} ; \mathrm{n}=19)$ biopsies were taken in early $(21$ to $28 \mathrm{DIM})$ and late $(245$ to 252 DIM) lactation. Asterisks indicate significant differences between early and late lactation: ${ }^{*} P<0.05, * * * P \leq 0.001$.

The number of mtDNA copies in peripheral blood was weakly correlated with mtDNA in liver $(\rho=0.343$; $P=0.026)$; however, no relation was observed with mtDNA of scAT and mammary gland. In addition, the mtDNA copy number from peripheral blood cells showed a moderate positive correlation with milk yield $(\rho=0.420 ; P=0.006)$ and a weak negative relationship with EB $(\rho=-0.355 ; P=0.023)$. The FA concentrations were negatively correlated with the mtDNA copy number in liver $(\rho=-0.421 ; P=0.006)$ and in scAT $(\rho=-0.418 ; P=0.007)$.

In early lactation, mtDNA copy numbers in peripheral blood were strongly correlated with mtDNA copies in liver $(\rho=0.727 ; P<0.001)$, $\operatorname{scAT}(\rho=0.762 ; P<$ $0.001)$, and in mammary gland $(\rho=0.711 ; P=0.001)$.
However, no relationship was observed between these variables in late lactation (Figure 5).

\section{DISCUSSION}

With the onset of lactation, energy requirements rapidly increase in high-yielding dairy cows due to milk production; voluntary feed intake does not usually increase as fast as does milk energy output. The adaption to lactation requires an elaborate regulation and coordination of energy metabolism among the key organs, such as AT, liver, and mammary gland (Barber et al., 1997; Block et al., 2001). Mitochondria are the main source for energy production in mammalian cells, and the mtDNA copy number, which reflects the abun- 
dance of mitochondria in a cell, can adapt to the energy demand and physiological condition of each individual (Al-Kafaji and Golbahar, 2013). Although mitochondria are ubiquitous in each cell, mitochondrial content, activity, and biogenesis can vary in different cell types in response to metabolic regulation (Lee et al., 2014). Mitochondrial membranes can be damaged by excessive TAG supply (Contreras and Sordillo, 2011), which is of particular interest in dairy cows, because of their dependence on fatty acids as a major energy source in the early postpartum period (Bauman and Currie, 1980). In mid and late lactation, the need for energy for milk synthesis is declining; however, the energy demands in
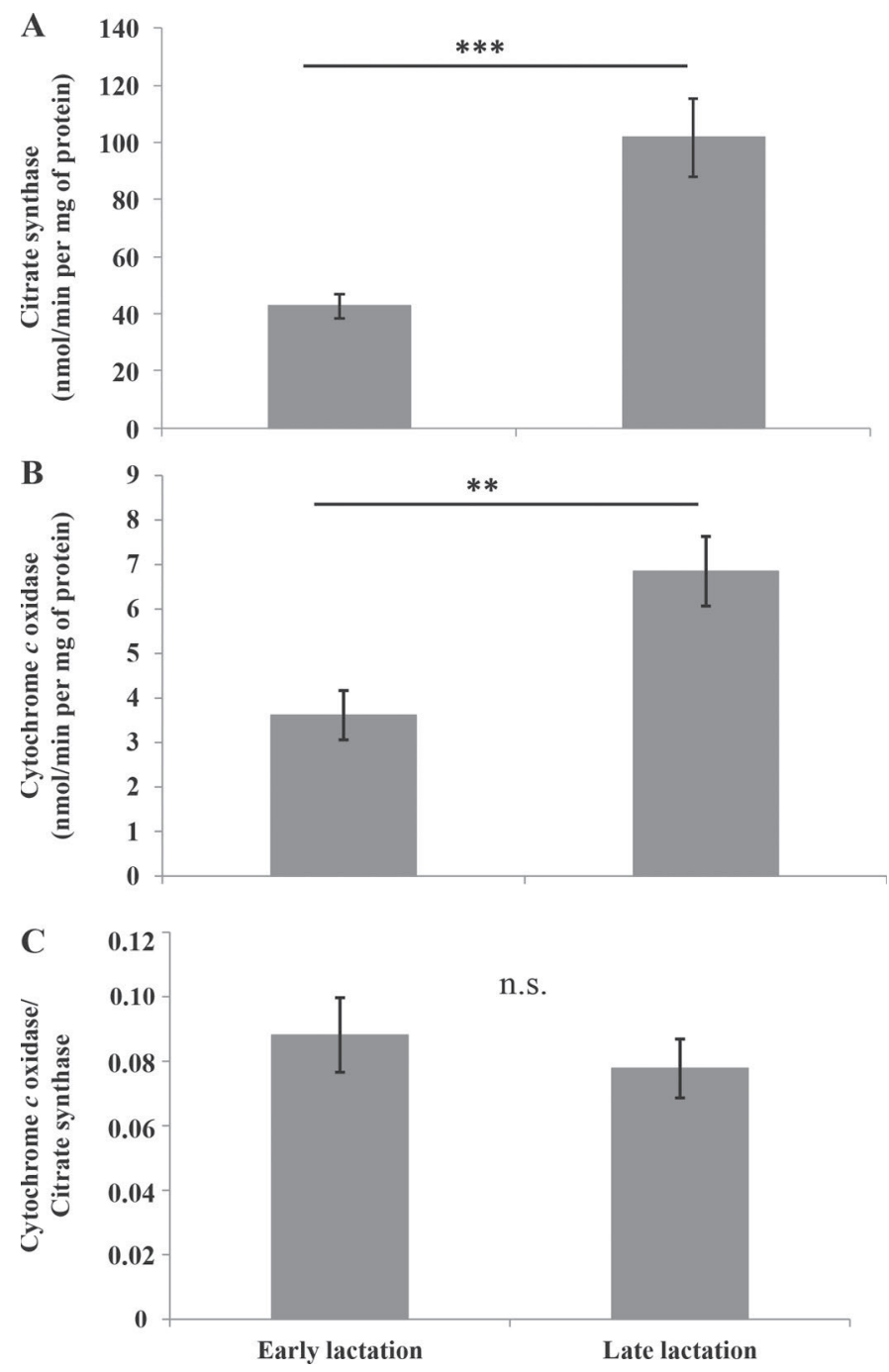

Figure 3. Activity of the mitochondrial enzymes citrate synthase (A; nmol/min per mg of protein), cytochrome $c$ oxidase $(\mathrm{B} ; \mathrm{nmol} / \mathrm{min}$ per $\mathrm{mg}$ of protein) and the ratio between cytochrome $c$ oxidase and citrate synthase $(\mathrm{C})$ in adipose tissue from high-yielding dairy cows ( $=21$ ) in early (21 to 28 DIM) and late (245 to 252 DIM) lactation. Data are presented as means $\pm \mathrm{SEM} ; * * * P \leq 0.001$, ${ }^{* *} P \leq 0.01$. high-yielding dairy cows are still high because of the needs for gestation, maintenance of lactation, and formation of body reserves for the next lactation period. An adequate population of healthy mitochondria is not only essential for cell survival but also guarantees the energy requirements for metabolically active organs throughout the entire lactation in dairy cows. To elucidate cellular energy status in high-yielding dairy cows, we aimed to determine the number of mtDNA copies and the mRNA expression of the main transcriptional regulators being involved in mitochondrial biogenesis in peripheral blood cells, scAT, liver, and mammary gland during early and late lactation.

\section{Tissue-Specific Differences in mtDNA Copy Numbers in Liver, Mammary Gland, and scAT}

The amount of mtDNA per cell differs widely among different cell types in rats and mice (Wellings et al., 1960). In the present study, the greatest number of mtDNA copies was observed in liver, in which the calculated mean mtDNA content of approximately 400 copies per cell corresponded well to values reported for rats using the same quantification method (Nicklas et al., 2004). Multiple metabolic processes; for example, glucose, lipid, and protein metabolism and ketogenesis, increase energy demands in bovine liver (Baldwin, 1995) that can further stimulate mtDNA content. In the present study, general metabolic parameters such as albumin, total protein, and glucose concentrations remained stable from early to late lactation, whereas indicators for lipid metabolism; that is, cholesterol and triglycerides, were increased, which might be interpreted as an upregulation of lipid metabolism in late lactation to provide substrates for lipogenesis. In the adaptation of these metabolic processes, the liver plays a central role, and increased activities of liver enzymes such as AST, GLDH, and GGT indicate metabolic stress and liver lesions (Giannini et al., 2005). Therefore, increased GLDH and GGT concentrations in late lactation that are beyond critical thresholds symptomatic for diseases might indicate that metabolism in general is stimulated. Decreased numbers of hepatic mitochondria in cows during negative EB, concomitant with decreased ATP content, were observed previously (Baird, 1980). This lack reduces the energy available for metabolic processes in the liver (e.g., for protein synthesis), as described by Baird (1980). In cows, increased mitotic activity of hepatocytes after calving (Reid and Collins, 1980) is followed by hepatocyte hypertrophy in mid lactation (Reid et al., 1980). However, in the current study, when comparing biopsies from early and late lactation, hepatocyte area remained stable. Based on the increased activity of liver enzymes, we propose that 

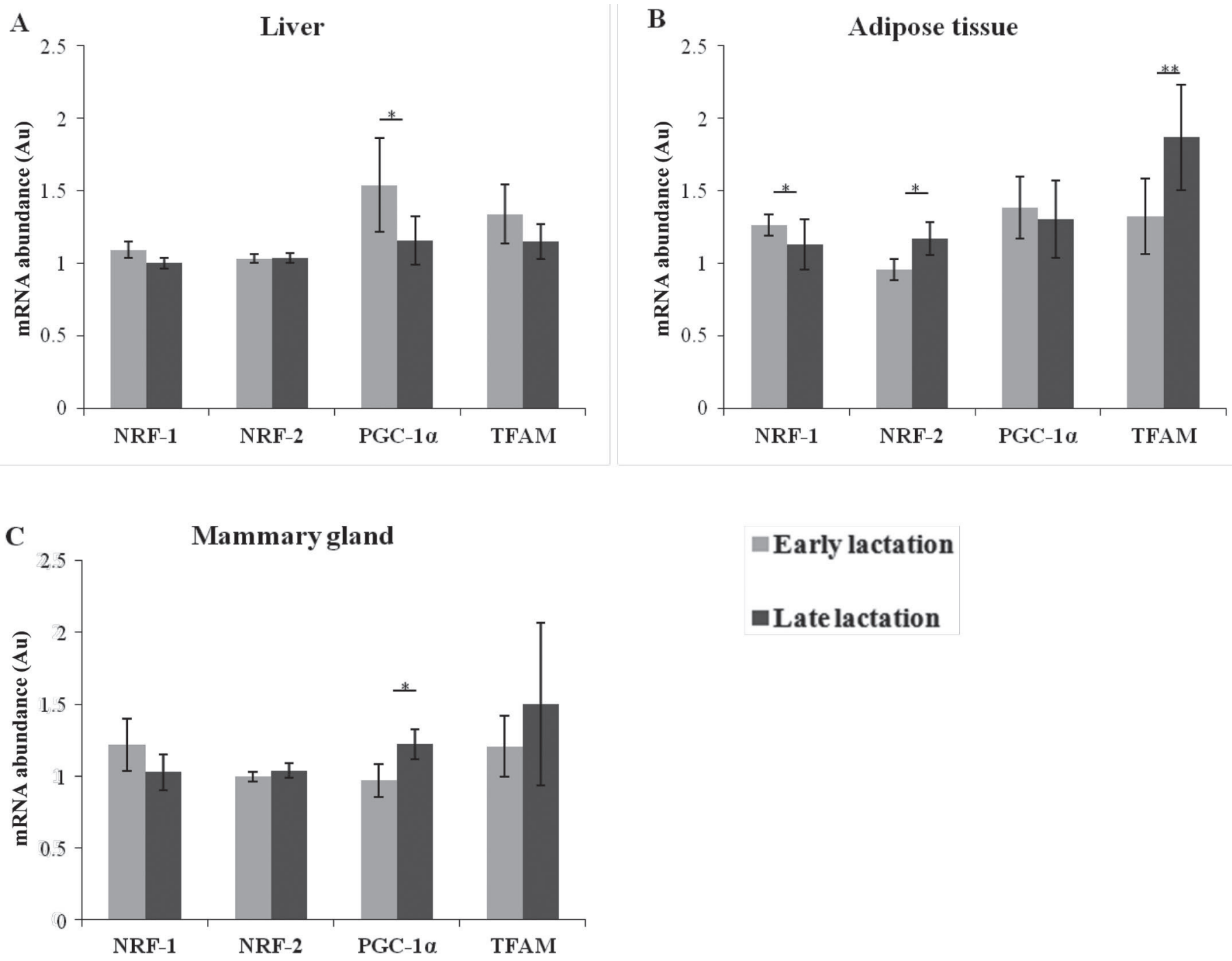

Early lactation

Late lactation

Figure 4. Messenger RNA abundance (geometric means $\pm \mathrm{SEM}$ ) of genes related to mitochondrial biogenesis $(N R F-1, N R F-2, P G C-1 \alpha$, and TFAM) in early and in late lactation in liver $(\mathrm{A} ; \mathrm{n}=21)$, adipose tissue $(\mathrm{B} ; \mathrm{n}=21)$, and mammary gland $(\mathrm{C} ; \mathrm{n}=15)$ biopsies. Data are normalized based on the geometric mean of the selected most stable reference genes. Asterisks indicate significant differences between early and late lactation: ${ }^{*} P<0.05,{ }^{* *} P \leq 0.01$.

Table 3. Spearman correlation coefficients between mitochondrial DNA (mtDNA) copy number per cell and gene expression of mitochondrial biogenesis variables in adipose tissue, liver, and mammary gland of lactating dairy cows $^{1}$

\begin{tabular}{|c|c|c|c|c|c|}
\hline Tissue & Item & $N R F-1$ & $N R F-2$ & $P G C-1 \alpha$ & TFAM \\
\hline \multirow[t]{4}{*}{ Adipose tissue } & mtDNA copy number & NS & 0.340 & NS & 0.388 \\
\hline & $N R F-1$ & - & 0.486 & 0.601 & 0.424 \\
\hline & $N R F-2$ & 0.486 & - & 0.487 & 0.954 \\
\hline & $P G C-1 \alpha$ & 0.601 & 0.487 & - & 0.555 \\
\hline \multirow[t]{4}{*}{ Liver } & mtDNA copy number & 0.515 & NS & NS & NS \\
\hline & $N R F-1$ & - & 0.370 & NS & NS \\
\hline & $N R F-2$ & 0.370 & - & NS & 0.384 \\
\hline & $P G C-1 \alpha$ & NS & NS & - & -0.349 \\
\hline \multirow[t]{4}{*}{ Mammary gland } & mtDNA copy number & NS & NS & NS & NS \\
\hline & $N R F-1$ & - & NS & -0.390 & 0.769 \\
\hline & $N R F-2$ & NS & - & 0.323 & NS \\
\hline & $P G C-1 \alpha$ & -0.390 & 0.323 & - & -0.352 \\
\hline
\end{tabular}

${ }^{1}$ Coefficients in bold font are significant at $P \leq 0.05$ and those in italic at $0.05<P \leq 0.1$. 

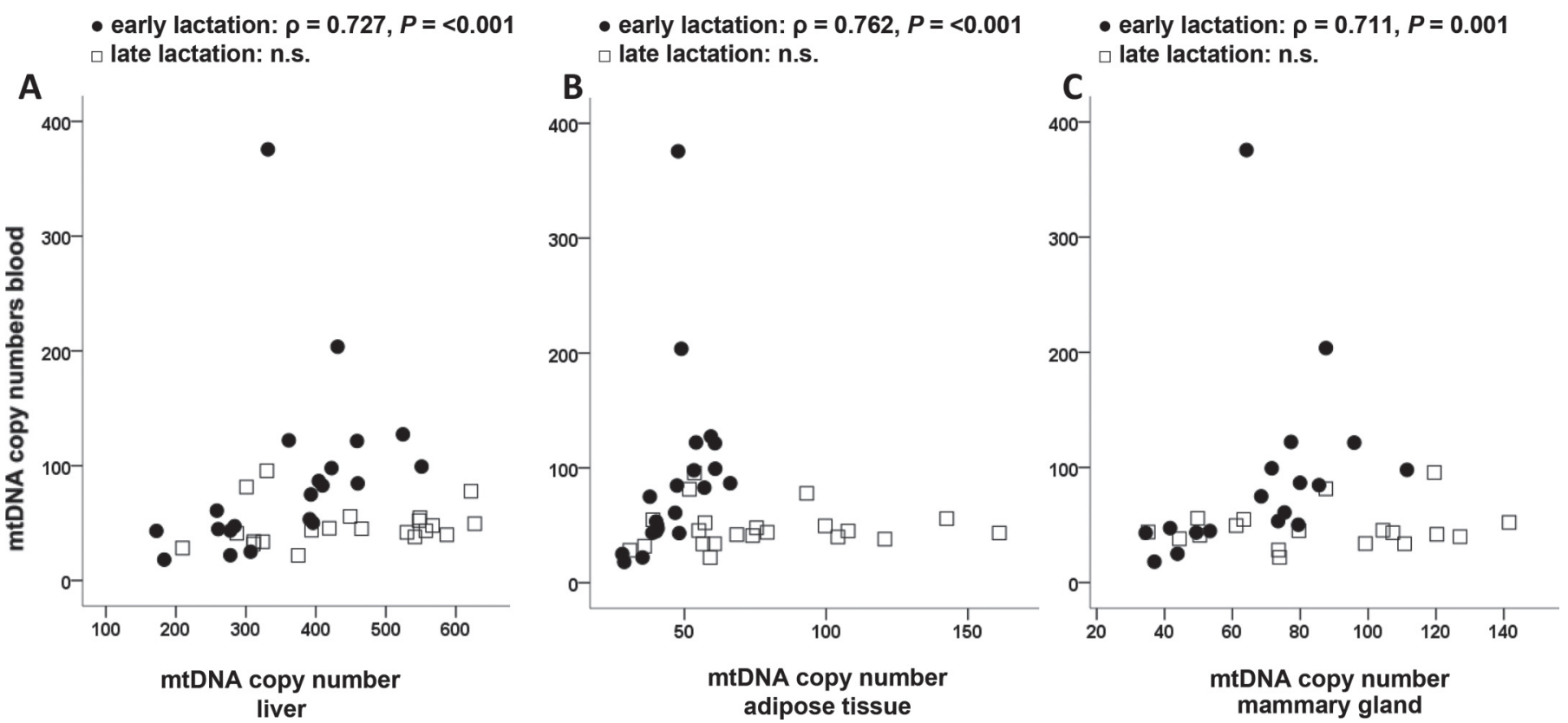

Figure 5. Relationships between mitochondrial DNA (mtDNA) copy numbers in peripheral blood and liver (A; $\mathrm{n}=21$ ), adipose tissue (B; $\mathrm{n}=21)$ as well as mammary gland $(\mathrm{C} ; \mathrm{n}=19)$ in high-yielding dairy cows from early (-; 21 to 28 DIM) and late ( $\square ; 245$ to 252 DIM) lactation; $P \leq 0.05$.

the higher mtDNA copy numbers were related to the increased metabolic activity rather than to hypertrophy of hepatocytes.

Together with the calculated negative EB, increased lipolysis as indicated by FA concentrations $>0.2 \mathrm{mmol} / \mathrm{L}$ (Drackley, 2000), indicates the high energy requirements in early lactation. Indeed, increased mtDNA copy numbers were observed in peripheral blood in early lactation compared with late lactation. However, the number of mtDNA copies in liver was increased in late lactation and negatively correlated with FA concentrations. Based on the negative relationship between circulating FA concentrations and the mtDNA copy number in liver and scAT, we suggest that elevated FA concentrations may downregulate the number of mtDNA, because FA increase reactive oxygen species and are known to damage mitochondrial proteins and mtDNA (Wathes et al. 2012). High FA concentrations following a high-fat feeding were reported to reduce the mtDNA content in AT of rats (Sutherland et al., 2008). In humans, the accumulation of fatty acids in visceral AT increased the synthesis of toxic fatty acid-delivered metabolites and thus elevated the level of oxidative stress, resulting in mitochondrial dysfunction accompanied by decreased mtDNA copy numbers (Lee et al., 2014). High-yielding dairy cows use FA released from AT as the major energy source when the glucose supply is limited right after calving (Bauman and Currie, 1980). This may predispose them to mitochondrial damage in a variety of tissues (Wathes et al. 2012) because genes located in the mitochondrial matrix are upregulated and promote the use of FA for energy production via the electron transport chain, resulting in increased production of reactive oxygen species (Wathes et al., 2012).

To determine mitochondrial activity in AT, we analyzed the activity of CS and Cox. Within the Krebs tricarboxylic acid cycle, CS is the rate-limiting enzyme and has often been used as a mitochondrial marker (Holloszy et al., 1970; Williams et al., 1986). Proliferation of mitochondria can be associated with increased CS activity (Eigentler et al., 2015). One of the complexes in the oxidative phosphorylation system is Cox (complex IV); the enzyme is located in the inner mitochondrial membrane and released in conjunction with mitochondrial damage (Renner et al., 2003). In the current study, both enzymes were increased from early to late lactation, supporting our findings of increased mtDNA content in AT. However, the Cox:CS ratio, which is thought to be a marker for mitochondrial function (Forini et al., 2014), remained constant throughout lactation.

Lipogenesis is an energy-consuming process, in which mitochondria must generate and provide sufficient ATP (Lu et al., 2010). In human white adipocytes, mtDNA content was strongly positively related to lipogenesis (Kaaman et al., 2007). Given that AT depots are refilled via lipogenesis during late lactation in dairy cows, the 
positive relation between BCS and mtDNA copy number in scAT might result from the lipogenic activity of AT. Recently, we found the same association between increasing BCS concomitant with increasing mtDNA copy numbers in AT of nonlactating cows after a dietinduced overconditioning (Laubenthal et al., 2015).

Milk production depends greatly upon mitochondrial ATP synthesis (Huang and Keenan, 1971). In humans and mice, the number of mitochondria increases to support lactogenesis during late pregnancy as well as the early postpartum period (until $8 \mathrm{~d}$ postpartum) and decreases thereafter (Wellings et al., 1960; Hollman, 1974; Rosano and Jones, 1976). Recently, Alex et al. (2015) observed increased mitochondria per mammary epithelium cell in early lactation, along with increased milk frequency in high-yielding dairy cows. Moreover, the number of mitochondria decreased from 15 DIM to 230 DIM (Alex et al., 2015). However, in the present study, mtDNA copies tended to increase from early (21-28 DIM) to late (245-252 DIM) lactation. Our results are comparable to the number of mitochondria in the mammary gland of lactating Chinese Holstein cows, which showed increased mitochondria from late pregnancy to late lactation (280 DIM), with the highest values after 60 DIM (Qu et al., 2012). During the course of lactation, the ATP concentrations in mammary gland cells change in cows, with greatest values during periods of peak milk production (Waldschmidt, 1973). Thus, the increasing number of mtDNA copies observed in the current study might expand the capacity for ATP synthesis within the mammary cells.

\section{Gene Expression of Regulators of $m t D N A$ Transcription}

In the lactation cycle, changes of mitochondrial function and biogenesis are related to milk production in mice (Hadsell et al., 2011). However, the regulation of mitochondrial biogenesis and function in dairy cows is poorly understood. Tissue-specific mtDNA copy numbers imply tissue-specific expression of genes involved in maintenance and regulation of mtDNA. Therefore, the expression of the genes encoding TFAM, PGC-1 $\alpha$, $N R F-1$, and NRF-2 was determined herein. Besides its role in mtDNA transcription, initiation, and mtDNA replication (Shadel and Clayton, 1993), TFAM is also important in mtDNA maintenance as a major component of the nucleoid (Kang et al., 2007). The results in scAT suggest that upregulation of TFAM might precede increasing mtDNA contents and thus enhance mtDNA transcription, as shown in humans (Pejznochova et al., 2010).

The expression of TFAM in turn is regulated by $N R F-1$ and NRF-2, whereas NRF-1 and NRF-2 mRNA abundances are affected by $P G C-1 \alpha$ (Virbasius and Scarpulla, 1994; Wu et al., 1999). The varying gene expression in different tissues observed in this study agrees with findings from Pejznochova et al. (2010). Mitochondrial transcription factors seemed to be expressed or regulated in a tissue-specific manner during lactation. Furthermore, Pejznochova et al. (2010) indicated transcriptional regulation of mitochondrial proliferation in liver, whereas in muscle, mitochondrial biogenesis could be regulated at the posttranscriptional or translational level. However, due to the lack of relationships between transcriptional factors and mtDNA copy numbers in mammary gland and liver, transcriptional regulation of mitochondrial proliferation seems to be limited to scAT in dairy cows.

\section{Blood Cell mtDNA as an Indicator for Tissue mtDNA Content in Dairy Cows}

Given that blood cells circulate in the whole body and organs, the mtDNA copy number in peripheral blood cells may reflect the mtDNA content in the investigated tissues. The weak correlation between peripheral blood mtDNA copy numbers and liver mtDNA copy numbers in the current study is in accordance with experiments in rats, in which changes in mtDNA content of peripheral blood leukocytes were accompanied by similar changes in hepatocyte mtDNA content (Chen et al., 2012). However, the lack of correlation between mtDNA copies in blood and in scAT or mammary gland is in line with a human study in patients with metabolic syndrome, whose reduced mtDNA copies in peripheral blood were not related to mtDNA content in white adipocytes (Mozhey et al., 2014). Thus, peripheral blood mtDNA copy numbers might not be an appropriate marker for tissue mtDNA content in dairy cows during the entire lactation. However, strong relationships were observed between the mtDNA copy number in blood and tissues when the comparison was limited to early lactation. In humans, peripheral blood mononuclear cells have been used as surrogate markers for changes in muscle and brain because their expression levels can change according to physiological and environmental events (Rudkowska et al., 2011; Lunnon et al., 2012). Therefore, we propose that in early-lactating dairy cows, mtDNA copy numbers in blood might reflect the current cellular energy status of scAT, liver, and mammary gland and may thus substitute tissue biopsies, which are more difficult to access.

\section{CONCLUSIONS}

In summary, the metabolic activity of the entire organism, as well as of single tissues and cells, can dif- 
fer between early and late lactation. That the greatest mtDNA copy numbers were found in liver, compared with other tissues and blood, supports the central metabolic role of this organ throughout the whole lactation. In dairy cows, both the onset and maintenance of lactation, together with gestation and formation of body reserves for the next lactation, influence cellular energy requirements, which was reflected by increasing mtDNA copy numbers in all tissues. In early-lactating dairy cows, blood mtDNA copy numbers may serve as a surrogate marker for the cellular energy status of tissues, in case tissue biopsies are difficult to access. The association between the mtDNA copy numbers and transcriptional factors during lactation was limited to scAT, and mitochondrial biogenesis seems to be regulated in a tissue-specific manner. However, further studies on the role of mitochondrial content, biogenesis, and function are needed to understand the complex mechanisms of cellular energy supply in dairy cows.

\section{ACKNOWLEDGMENTS}

The authors thank the Deutsche Forschungsgemeinschaft (DFG, Bonn, Germany) for financial support (HA 6026/3-1). Lilian Laubenthal was recipient of a scholarship from the Landesgraduiertenförderung NRW. The assistance of the staff of the Experimental Station Frankenforst of the Faculty of Agriculture, University of Bonn (Königswinter, Germany) is gratefully acknowledged. Furthermore, we thank Iris Gockel-Böhner (University of Bonn) for her excellent technical assistance in the animal experiments. In addition, we appreciate the technical assistance of Barbara Heitkönig, Inga Hofs, and Natascha Stumpf (University of Bonn). This research was conducted in the Center of Integrated Dairy Research (CIDRe), University of Bonn (Bonn, Germany).

\section{REFERENCES}

Al-Kafaji, G., and J. Golbahar. 2013. High glucose-induced oxidative stress increases the copy number of mitochondrial DNA in human mesangial cells. Biomed. Res. Int. 2013:754946.

Alberti, A., L. Bolognini, D. Macciantelli, and M. Caratelli. 2000. The radical cation of $\mathrm{N}, \mathrm{N}$-diethyl-para-phenylendiamine: A possible indicator of oxidative stress in biological samples. Res. Chem. Intermed. 26:253-267.

Alex, A. P., J. L. Collier, D. L. Hadsell, and R. J. Collier. 2015. Milk yield differences between $1 \mathrm{x}$ and $4 \mathrm{x}$ milking are associated with changes in mitochondrial number and milk protein gene expression, but not mammary cell apoptosis or SOCS gene expression. J. Dairy Sci. 98:4439-4448.

Baird, G. D. 1980. Liver metabolism in the dairy cow: Problems involved in meeting the demands of high productivity. Pages 87-93 in Proc. Int. Conf. Production Disease in Farm Animals. D. Giesecke, G. Dirksen, and M. Stangassinger, ed. München, Germany.

Baldwin, R. L. 1995. Modeling Ruminant Digestion and Metabolism. Chapman \& Hall, London, UK.
Barazzoni, R., K. R. Short, and K. S. Nair. 2000. Effects of aging on mitochondrial DNA copy number and cytochrome c oxidase gene expression in rat skeletal muscle, liver, and heart. J. Biol. Chem. 275:3343-3347.

Barber, M. C., R. A. Clegg, M. T. Travers, and R. G. Vernon. 1997. Lipid metabolism in the lactating mammary gland. Biochim. Biophys. Acta 1347:101-126.

Bauman, D. E., and W. B. Currie. 1980. Partitioning of nutrients during pregnancy and lactation: a review of mechanisms involving homeostasis and homeorhesis. J. Dairy Sci. 63:1514-1529.

Block, S. S., W. R. Butler, R. A. Ehrhardt, A. W. Bell, M. E. Van Amburgh, and Y. R. Boisclair. 2001. Decreased concentration of plasma leptin in periparturient dairy cows is caused by negative energy balance. J. Endocrinol. 171:339-348.

Brown, D. E., C. D. Dechow, W. S. Liu, K. J. Harvatine, and T. L. Ott. 2012. Hot topic: association of telomere length with age, herd, and culling in lactating Holsteins. J. Dairy Sci. 95:6384-6387.

Castañeda-Gutiérrez, E., S. H. Pelton, R. O. Gilbert, and W. R. Butler. 2009. Effect of peripartum dietary energy supplementation of dairy cows on metabolites, liver function and reproductive variables. Anim. Reprod. Sci. 112:301-315.

Cawthon, R. M. 2009. Telomere length measurement by a novel monochrome multiplex quantitative PCR method. Nucleic Acids Res. $37: \mathrm{e} 21$.

Chen, X., S. Wei, and F. Yang. 2012. Mitochondria in the pathogenesis of diabetes: A proteomic view. Protein Cell 3:648-660.

Contreras, G. A., and L. M. Sordillo. 2011. Lipid mobilization and intramammary responses during the transistion period of dairy cows. Comp. Immunol. Microbiol. Infect. Dis. 34:281-289.

Drackley, J. K. 1999. ADSA Foundation Scholar Award. Biology of dairy cows during the transition period: The final frontier? J. Dairy Sci. 82:2259-2273.

Drackley, J. K. 2000. Use NEFA as a tool to monitor energy balance in transition dairy cows. Illinois Dairy Days. http://livestocktrail. illinois.edu/dairynet/paperDisplay.cfm?ContentID=330.

Edmonson, A., I. J. Lean, L. D. Weaver, T. Farver, and G. Webster 1989. A body condition scoring chart for Holstein dairy cows. J. Dairy Sci. 72:68-78.

Eigentler, A., A. Draxl, A. Wiethüchter, A.V. Kuznetsov, B. Lassing, and E. Gnaiger. 2015. Laboratory protocol: Citrate synthase a mitochondrial marker enzyme. Mitochond. Physiol. Netw. 17.04:1-11.

Fawcett, D. 1981. The Cell. Pages 410-468. 2nd ed. W. B. Saunders Company, Philadelphia, PA.

Forini, F., C. Kusmic, G. Nicolini, L. Mariani, R. Zucchi, M. Matteucci, G. Iervasi, and L. Pitto. 2014. Triiodothyronine Prevents cardiac ischemia/reperfusion mitochondrial impairment and cell loss by regulating miR30a/p53 axis. Endocrinology 155:4581-4590.

GfE. 1991. Leitlinien für die Bestimmung der Verdaulichkeit von Rohnährstoffen an Wiederkäuern. J. Anim. Physiol. Anim. Nutr. (Berl.) 65:229-234.

GfE. 2001. Empfehlungen zur Energie- und Nährstoffversorgung der Milchkühe und Aufzuchtrinder. DLG Verlag, Frankfurt am Main, Germany.

Giannini, E. G., R. Testa, and V. Savarino. 2005. Liver enzyme alteration: A guide for clinicians. CMAJ 172:367-379.

Hadsell, D. L., O. W. Olea, J. Wei, M. L. Fiorotto, R. K. Matsunami, D. A. Engler, and R. J. Collier. 2011. Developmental regulation of mitochondrial biogenesis and function in the mouse mammary gland during a prolonged lactation cycle. Physiol. Genomics 43:271-285.

Hollman, K. H. 1974. Cytology and fine structure of the mammary gland. Pages 3-95 in Lactation: A Comprehensive Treatise. Vol. 1. B. L. Larson and V. R. Smith, ed. Academic Press, New York, NY.

Holloszy, J. O., L. B. Oscai, I. J. Don, and P. A. Mole. 1970. Mitochondrial citric acid cycle and related enzymes: Adaptive response to exercise. Biochem. Biophys. Res. Commun. 40:1368-1373.

Hosseini, A., H. Sauerwein, and M. Mielenz. 2010. Putative reference genes for gene expression studies in propionate and beta-hydroxybutyrate treated bovine adipose tissue explants. J. Anim. Physiol. Anim. Nutr. (Berl.) 94:e178-e184. 
Huang, C. M., and T. W. Keenan. 1971. Membranes of mammary gland. Bovine mammary mitochondria. J. Dairy Sci. 54:1395-1405.

Izquierdo, J. M., J. Ricart, L. K. Ostronoff, G. Egea, and J. M. Cuezva. 1995. Changing patterns of transcriptional and posttranscriptional control of beta-F1-ATPase gene expression during mitochondrial biogenesis in liver. J. Biol. Chem. 270:10342-10350.

Kaaman, M., L. M. Sparks, V. van Harmelen, S. R. Smith, E. Sjolin, I. Dahlman, and P. Arner. 2007. Strong association between mitochondrial DNA copy number and lipogenesis in human white adipose tissue. Diabetologia 50:2526-2533.

Kang, D., S. H. Kim, and N. Hamasaki. 2007. Mitochondrial transcription factor A (TFAM): Roles in maintenance of mtDNA and cellular functions. Mitochondrion 7:39-44.

Laubenthal, L., L. Locher, N. Sultana, J. Winkler, U. Meyer, J. Rehage, S. Dänicke, H. Sauerwein, and S. Häussler. 2015. Relationship between circulating leptin concentrations and adipocyte mitochondria in nonlactating dairy cows during a course of overcondition. Proc. Soc. Nutr. Physiol. 24:115. (Abstr.)

Lee, J. Y., D. C. Lee, J. A. Im, and J. W. Lee. 2014. Mitochondrial DNA copy number in peripheral blood is independently associated with visceral fat accumulation in healthy young adults. Int. J. Endocrinol. 2014:586017.

Lu, R. H., H. Ji, Z. G. Chang, S. S. Su, and G. S. Yang. 2010. Mitochondrial development and the influence of its dysfunction during rat adipocyte differentiation. Mol. Biol. Rep. 37:2173-2182.

Lunnon, K., Z. Ibrahim, P. Proitsi, A. Lourdusamy, S. Newhouse, M. Sattlecker, S. Furney, M. Saleem, H. Soininen, I. Kloszewska, P. Mecocci, M. Tsolaki, B. Vellas, G. Coppola, D. Geschwind, A. Simmons, S. Lovestone, R. Dobson, and A. Hodges., and AddNeuroMed Consortium. 2012. Mitochondrial dysfunction and immune activation are detectable in early Alzheimer's disease blood. J. Alzheimers Dis. 30:685-710.

Mozhey, O. I., P. A. Zatolokin, M. A. Vasilenko, L. S. Litvinova, E. V. Kirienkova, and I. O. Mazunin. 2014. Evaluating the number of mitochondrial DNA copies in leukocytes and adipocytes from metabolic syndrome patients: Pilot study. Mol. Biol. (Mosk.) 48:590-593

Nicklas, J. A., E. M. Brooks, T. C. Hunter, R. Single, and R. F. Branda. 2004. Development of a quantitative PCR (TaqMan) assay for relative mitochondrial DNA copy number and the common mitochondrial DNA deletion in the rat. Environ. Mol. Mutagen. 44:313-320.

Pejznochova, M., M. Tesarova, H. Hansikova, M. Magner, T. Honzik, K. Vinsova, Z. Hajkova, V. Havlickova, and J. Zeman. 2010 Mitochondrial DNA content and expression of genes involved in mtDNA transcription, regulation and maintenance during human fetal development. Mitochondrion 10:321-329.

Qu, B., Y. Jiang, F. Zhao, J. Xiao, and Q. Z. Li. 2012. Changes of endoplasmic reticulum and mitochondria in mammary epithelial cells during mammogenesis in Chinese Holstein dairy cows. Acta Histochem. 114:448-453.

Regenhard, P., D. Nakov, and H. Sauerwein. 2014. Applicability of a spectrophotometric method for assessment of oxidative stress in poultry. Mac. Vet. Rev. 37:43-47.

Reid, I. M., and R. A. Collins. 1980. The pathology of post-parturient fatty liver in high-yielding dairy cows. Invest. Cell Pathol. $3: 237-249$.
Reid, I. M., C. J. Roberts, and G. D. Baird. 1980. The effects of underfeeding during pregnancy and lactation on structure and chemistry of bovine liver and muscle. J. Agric. Sci. 94:239-245.

Renner, K., A. Amberger, G. Konwalinka, R. Kofler, and E. Gnaiger. 2003. Changes of mitochondrial respiration, mitochondrial content and cell size after induction of apoptosis in leukemia cells. Biochim. Biophys. Acta 1642:115-123.

Rosano, T. G., and D. H. Jones. 1976. Developmental changes in mitochondria during the transition into lactation in the mouse mammary gland. J. Cell Biol. 69:573-580.

Rudkowska, I., C. Raymond, A. Ponton, H. Jacques, C. Lavigne, B. J. Holub, A. Marette, and M. C. Vohl. 2011. Validation of the use of peripheral blood mononuclear cells as surrogate model for skeletal muscle tissue in nutrigenomic studies. OMICS 15:1-7.

Saremi, B., A. Al-Dawood, S. Winand, U. Müller, J. Pappritz, D. von Soosten, J. Rehage, S. Dänicke, S. Häussler, M. Mielenz, and H. Sauerwein. 2012. Bovine haptoglobin as an adipokine: Serum concentrations and tissue expression in dairy cows receiving a conjugated linoleic acids supplement throughout lactation. Vet. Immunol. Immunopathol. 146:201-211.

Shadel, G. S., and D. A. Clayton. 1993. Mitochondrial transcription initiation. Variation and conservation. J. Biol. Chem. 268:1608316086 .

Sutherland, L. N., L. C. Capozzi, N. J. Turchinsky, R. C. Bell, and D. C. Wright. 2008. Time course of high-fat diet-induced reductions in adipose tissue mitochondrial proteins: potential mechanisms and the relationship to glucose intolerance. Am. J. Physiol. Endocrinol. Metab. 295:E1076-E1083.

Villarroya, J., M. Giralt, and F. Villarroya. 2009. Mitochondrial DNA: An up-and-coming actor in white adipose tissue pathophysiology. Obesity (Silver Spring) 17:1814-1820.

Virbasius, J. V., and R. C. Scarpulla. 1994. Activation of the human mitochondrial transcription factor A gene by nuclear respiratory factors: a potential regulatory link between nuclear and mitochondrial gene expression in organelle biogenesis. Proc. Natl. Acad. Sci. USA 91:1309-1313.

Waldschmidt, M. 1973. Metabolite levels and enzyme activities in the bovine mammary gland at different stages of lactation: I. Metabolite levels related to energy production. J. Dairy Res. 40:7-15.

Wathes, D. C., A. M. Clempson, and G. E. Pollott. 2012. Association between lipid metabolism and fertility in the dairy cow. Reprod. Fertil. Dev. 25:48-61.

Wellings, S. R., K. B. Deome, and D. R. Pitelka. 1960. Electron microscopy of milk secretion in the mammary gland of the $\mathrm{C} 3 \mathrm{H} / \mathrm{Crgl}$ mouse. I. Cytomorphology of the prelactating and the lactating gland. J. Natl. Cancer Inst. 25:393-421.

Williams, R. S., S. Salmons, E. Newsholme, R. E. Kaufman, and J. Mellor. 1986. Regulation of nuclear and mitochondrial gene expression by contractile activity in skeletal muscle. J. Biol. Chem. 261:376-380.

Wu, Z., P. Puigserver, U. Andersson, C. Zhang, G. Adelmant, V. Mootha, A. Troy, S. Cinti, B. Lowell, R. C. Scarpulla, and B. M. Spiegelman. 1999. Mechanisms controlling mitochondrial biogenesis and respiration through the thermogenic coactivator PGC-1. Cell 98:115-124. 